3a. External pacemaker.

Check external wires and connexions and replace six-monthly.

Check power of pacemaker. Batteries changed 6- to 12monthly.

3b. Implanted pacemaker.

Check power with measuring oscilloscope.

\section{Results}

Ninety-six patients with permanent pacemakers have been followed up. The total number of faults and pacingbreakdowns has been large, but these are now becoming fewer with the introduction of better techniques. Furthermore, the majority of patients have been able to lead normal lives. Only one patient has died as a direct result of unit failure; the remainder survived a recurrence of Stokes-Adams attacks because of return of idioventricular rhythm giving sufficient time for restoration of artificial pacing.

\section{Summary}

Ninety-six patients with long-term artificial pacemakers have been followed up at a special out-patient clinic. Their types of pacing systems are described and normal pacing patterns are outlined. The causes of faulty pacing and their manifestations are discussed, with the techniques routinely used in the clinic to correct such faults and to maintain regular pacing.

REFERENCES

Davies, J. G., and Sowton, G. E. (1964). Phys. in Med. Biol., 9, 257. Harris, A., Bluestone, R., Busby, E., Davies, G., Leatham, A., Siddons, H., and Sowton, E.' (1965). "'The Management of Heart Block." Brit. Heart F., 1965 . In press.

Segel, N., Hudson, W. A., Harris, P., and Bishop, J. M. (1964). F. clin. Invest., 43, 1541.

Siddons, H., and Davies, J. G. (1963). Lancet, 2, 1204

Sowton, G. E. (1963). M.D. Thesis, Cambridge.

- and Davies, J. G. (1964). Brit. med. F., 1, 1470

\title{
Hodgkin's Disease, Autoimmunity, and the Thymus
}

\author{
B. I. HOFFBRAND,* M.A., B.M., B.CH., M.R.C.P.
}

Brit. med. F., 1965, 1, 1592-1594

The immunological features of Hodgkin's disease have been recently reviewed by Aisenberg (1964). The high incidence in this condition of certain infections, tuberculosis, cryptococcosis, and herpes zoster has been recognized for some years (Ewing, 1940 ; Collins et al., 1951 ; Williams et al., 1959). This susceptibility to predominantly intracellular organisms is now thought to be related to impaired tuberculin-like delayed hypersensitivity, an immunological defect found in a large percentage of patients with Hodgkin's disease, even at an early stage of the disease (Schier et al., 1956). The production of circulating antibodies, on the other hand, is generally well preserved (Aisenberg and Leskowitz, 1963) and frank hypogammaglobulinaemia is rare (Hoffbrand, 1964a).

There have been repeated suggestions that autoimmune mechanisms play a part in Hodgkin's disease. Kaplan and Smithers (1959) pointed out the similarities of graft-versus-host reactions such as runt-disease to Hodgkin's disease, especially to its occasional acute terminal illness with fever, wasting, anaemia, leucopenia, and lymphoid depletion. Green et al. (1960) suggested that Hodgkin's disease could represent a maternal-foetal lymphoid chimaera. Waksman (1962) includes Hodgkin's disease in a review of diseases of unknown aetiology in which autoimmunity may occur.

There are also numerous reports of the occurrence in Hodgkin's disease of disorders believed to have an autoimmune basis. Beuchart (1958) and Cammarata et al. (1963) describe cases of Hodgkin's disease, with clinical and pathological evidence of systemic lupus erythematosus (S.L.E.). Miescher and Vorlaender (1957) and Ogryzlo (1956) report cases with positive lupus erythematosus (L.E.) cell tests. Haematoxylin bodies, thought to be pathognomonic of S.L.E., have been found in Hodgkin's tissue (Candreviotis, 1962). Razis et al. (1959) found two cases of polyarteritis nodosa, one of probable scleroderma, and one with previous thrombocytopenic purpura treated by splenectomy among 1,102 cases of Hodgkin's disease. Hench et al. (1962) report 22 patients among 1,000 cases of unspecified lymphoma who had significant rheumatic complaints, including rheumatoid arthritis, S.L.E., and polyarteritis. Positive latex-fixation tests in the reticuloses, in the

- Medical Registrar, University College Hospital, London. Present address: Whittington Hospital, London. absence of liver disease, have been attributed to abnormalities of the antibody-producing cells of the body (Innis and Ferguson, 1964). Howqua and Mackay (1963), in a paper describing the finding of L.E. cells, antinuclear antibodies (A.N.F.), and organ-specific antibodies in cases of malignant lymphoma, including Hodgkin's disease, discuss the significance of autoimmune phenomena in the reticuloses in terms of Burnet's clonal selection theory (Burnet, 1959).

Further possible pointers to the existence of immune mechanisms in Hodgkin's disease are the frequent occurrence in this condition of hypergammaglobulinaemia (Miller, 1962) and of involvement of the thymus (Thomson, 1955). The cause of the former is unknown. The significance, other than local, of the latter is also uncertain, though Thomson (1955) found a higher incidence of thymic involvement in females and an associated improved survival rate. Aisenberg (1964) has pointed out the need, with new knowledge of its function, for a reappraisal of the thymus gland in Hodgkin's disease.

This paper reports a study of thymic involvement and of clinical and serological evidence of autoimmune phenomena in Hodgkin's disease.

\section{Material and Methods}

The patients were 39 cases of histologically proved Hodgkin's disease attending the lymphoma clinic at University College Hospital. The histology of the gland sections had all been carefully reviewed and only those showing typical features of the disease were included (Hilton and Sutton, 1962). All the patients were seen regularly in the clinic, were fully documented, and had had chest radiographs carried out when first seen and at frequent intervals afterwards. All the patients, except for two not treated after the initial gland biopsy and one who had had drug therapy only, had had one or more courses of radiotherapy.

Radiological evidence of upper anterior mediastinal disease at any time during the period of observation was noted and assumed to indicate thymic involvement. Those without such changes were considered to have an uninvolved thymus. Such assumptions are obviously liable to error but were felt to be warranted for comparative purposes. 
Serum was obtained from each patient and stored at $-20^{\circ} \mathrm{C}$. Serum gamma-globulin levels were estimated by elution from a paper electrophoretic strip (Franglen and Martin, 1961), the total protein content being measured by the biuret method. The mean of duplicate strips agreeing within $100 \mathrm{mg} . / 100 \mathrm{ml}$. was recorded.

Thyroid (cytoplasmic and colloid), gastric parietal cell, and antinuclear (A.N.F.) antibodies were sought by the combined immunofluorescent test (Doniach et al., 1963). The tests were done in duplicate with known positive and negative sera in every batch as control. In one series a commercially available ${ }^{1}$ fluorescein-conjugated goat anti-human-globulin antiserum was used. In the second series of tests a fluorescein-conjugated rabbit anti-human-globulin antiserum ${ }^{2}$ was used with prior absorption with pig-liver powder. Rheumatoid factor was sought by the Hyland R.A. latex-fixation test. Hodgkin's sera found to have A.N.F. were tested for L.E. factor by the Hyland L.E. latex-fixation method.

\section{Results}

The clinical details of the patients are given in the Table, in which a comparison is made between those patients with and those without thymic involvement. The upper limit of normal of the serum gamma-globulin in this laboratory is $1.33 \mathrm{~g} . / 100$ $\mathrm{ml}$.

Clinical Details at Time of Serological Examination in 39 Cases of

\begin{tabular}{|c|c|c|}
\hline & $\begin{array}{c}\text { Thymic } \\
\text { Involvement }\end{array}$ & $\begin{array}{l}\text { No Thymic } \\
\text { Involvement }\end{array}$ \\
\hline 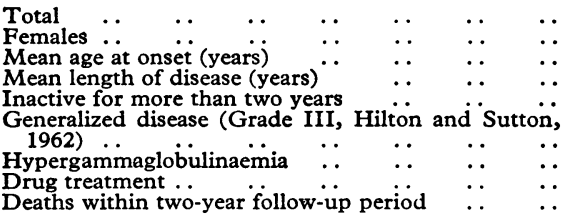 & $\begin{array}{c}21 \\
8 \\
31 \cdot 5 \\
4 \cdot 1 \\
3\end{array}$ & $\begin{array}{c}18 \\
7 \\
33 \cdot 7 \\
5 \cdot 3 \\
5\end{array}$ \\
\hline
\end{tabular}

\section{Evidence of Autoimmune Disease}

Clinical.-There was no convincing evidence of autoimmune disease among these 39 cases of Hodgkin's disease. One woman of 22 with a raised serum gamma-globulin had had previous thyrotoxicosis and partial thyroidectomy of a nodular gland. Two patients with normal or low serum gamma-globulin levels were found to have small nodular goitres at necropsy. Apart possibly from an elderly man who had pain around his shoulders that improved on local heat treatment, there was no evidence of systemic rheumatic disease. During the period of observation there was no case of autoimmune haemolytic anaemia, though two patients with immunoglobulin deficiencies had Coombs-negative haemolytic states (Hoffbrand, 1964b).

Of the 11 patients who died in the approximately two-year follow-up period three had fulminating terminal illnesses similar to that described by Kaplan and Smithers (1959) and mentioned above. One had raised and another had low serum gamma-globulin levels one month before death. The third, who also had thymic involvement radiologically, had a normal level when tested 16 months before he died.

Serological.-Thyroid antibodies were absent in all cases. Gastric antibodies, A.N.F., and a weak positive R.A. latexfixation test were each found separately in one case only. All three patients had hypergammaglobulinaemia but none had thymic involvement and their clinical picture was unexceptional, though the patient with A.N.F. later had an attack of shingles.

\footnotetext{
'Stayne Laboratories.
2 Provided by Dr. P. J. Lachmann.
}

L.E. latex testing of the A.N.F.-containing serum was negative. This incidence of $2.6 \%$ of positive results of both organ and non-organ specific antibodies is well within that found in normal control populations (Gell and Coombs, 1963).

\section{Thymic Involvement}

This occurred at some stage during the period of observation in $21(54 \%)$ of the patients. In $13(33 \%)$ patients thymic disease had been noted within the previous two years. In none of the six cases which came to necropsy was there any discrepancy between radiological and post-mortem evidence of thymic involvement. The Table shows no apparent differences between the groups with and without thymic involvement ; in particular, the sex incidence, the percentage with raised serum gamma-globulin levels, and the percentage of deaths during the two years after serum examination were the same in the two groups. The clinical progress of the four patients in whom Hodgkin's disease presented with a thymic mass was in no way remarkable.

\section{Serum Gamma-globulin Levels}

Twelve ( $31 \%$ ) had raised serum gamma-globulin levels. The degree of hypergammaglobulinaemia was modest in all cases, the highest level being only $1.7 \mathrm{~g} . / 100 \mathrm{ml}$. As noted above, hypergammaglobulinaemia was not related to thymic involvement. It is interesting to note that of the 11 deaths, 10 occurred among the 27 patients with normal or low serum gamma-globulin levels. These deaths occurred one to 21 (mean 8.7) months after the serum examination.

\section{Discussion}

This investigation has failed to reveal clinical or serological evidence of autoimmune phenomena in Hodgkin's disease. Though cytotoxic drugs and steroids are of value in the treatment of autoimmune states (Dameshek and Schwartz, 1960), the absence of auto-antibodies in the present study cannot be attributed to such therapy. Less than one-third of the patients had had such treatment at the time blood was taken. Moreover, in spite of good clinical results, cytotoxic drugs do not affect the levels of auto-antibodies (Dameshek and Schwartz, 1960), while the effect of steroids in this respect is variable (Mackay and Burnet, 1962).

As there are few characteristic serological changes recorded as yet in experimental graft-versus-host reactions (Simonsen, 1962) the present negative findings cannot be said to rule out such reactions in Hodgkin's disease. However, serum gammaglobulin levels are rarely raised in the experimental condition (Oliner et al., 1961), whereas raised levels are common in Hodgkin's disease.

Radiological evidence of thymic involvement within one year of presentation was found in $111(40.4 \%)$ of 275 cases of Hodgkin's disease by Thomson (1955). He showed a higher incidence of thymic disease in females together with an improved survival rate. Marshall and Wood (1957) found macroscopic evidence of thymic involvement in only $26 \%$ of 86 necropsy cases of Hodgkin's disease. They could not confirm Thomson's findings as to sex incidence and prognosis. The present study shows an overall incidence greater than that found by Thomson, as expected with the longer period at risk. The incidence with treatment approached Marshall and Wood's figure, exactly one-third of the 39 having had thymic disease within the previous two years. The present findings are also in keeping with those of the latter authors as to the apparent absence of wider clinical significance.

The cause of hypergammaglobulinaemia in Hodgkin's disease is unknown and has been variously related to relapses of the 
disease (Teitelbaum et al., 1959), chronic inflammation (Cazal et al., 1956), and to successful response to treatment (Wall, 1958). This study has shown that raised serum gammaglobulin levels in Hodgkin's disease cannot be looked on as evidence of antibody activity related to thymic involvement.

The tendency of the serum gamma-globulin to fall just before death has been previously noted (Wall, 1958). Similarly in the present study almost all the deaths occurred in the normal or low serum gamma-globulin group. The significance of this is a matter for conjecture but it seems possible that it represents some failure in resistance, provided by circulating antibody.

\section{Summary}

There have been numerous reports of the occurrence in Hodgkin's disease of disorders believed to have an autoimmune basis. However, no evidence of autoimmune phenomena has been found in a clinical and serological survey of 39 cases of histologically proved Hodgkin's disease. The possibility that changes equivalent to experimental graft-versus-host reactions occur in this disease remains.

There was no evidence from this study to suggest that involvement of the thymus, a frequent occurrence in Hodgkin's disease, is of other than local significance. Raised serum gamma-globulin levels are not related to thymic disease and the cause of this finding in Hodgkin's disease remains unknown. Though one-third of the patients in this series had hypergammaglobulinaemia, almost all those who died had had normal or low serum gamma-globulin levels 21 or fewer months before death. It is possible that this serological feature represents a failure in resistance to the disease normally provided by circulating antibody.

I am grateful to Professor T. A. J. Prankerd for continuous encouragement, to Drs. D. Doniach, F. V. Flynn, and P. J. Lachmann for technical advice, to Drs. E. W. Emery and J. N. Godlee for access to patients under their care, and to the Research Funds of University College Hospital for financial support.
REFERENCES

Aisenberg, A. C. (1964). New Engl. F. Med., 270, 617.

- and Leskowitz, S. (1963). Ibid., 268, 1269.

Beuchart, A. (1958). Ärztl. W schr., 13, 438.

Burnet, F. M. (1959). The Clonal Selection Theory of Acquired Immunity. Cambridge University Press, Cambridge.

Cammarata, R. J., Rodnan, G. P., and Jensen, W. N. (1963). Arch. intern. Med., $111,330$.

Candreviotis, N. (1962). 7. clin. Path., 15, 542.

Cazal, P., Carli, G., and Fischer, J. (1956). Presse méd., 64, 184.

Collins, V. P., Gellhorn, A., and Trimble, J. R. (1951). Cancer (Philad.), 4, 883 . Dameshek, W., and Schwartz, R. (1960). Trans. Ass. Amer. Phycns,
73, 113.

Doniach, D., Roitt, I. M., and Taylor, K. B. (1963). Brit. med. F., 1, 1374.

Ewing, J. (1940). Neoplastic Diseases, 4th ed. Saunders, Philadelphia.

Franglen, G., and Martin, N. (1961). Broadsheet No. 37 (N.S.). Published by the Association of Clinical Pathologists.

Gell, P. G. H., and Coombs, R. R. A. (1963). Clinical Aspects of Immunology. Blackwell, Oxford.

Green, I., Inkelas, M., and Allen, L. B. (1960). Lancet, 1, 30.

Hench, P. K., Mayne, J. G., Kiely, J. M., and Dockerty, M. B. (1962). Arthr. and Rheum., 5, 301.

Hilton, G., and Sutton, P. M. (1962). Lancet, 1, 283.

Hoffbrand, B. I. (1964a). Brit. med. F., 1, 1156.

(1964b). Brit. F. Cancer, 18, 98.

Howqua, J., and MacKay, I. R. (1963). Blood, 22, 191

Innis, M. D., and Ferguson, N. W. (1964). Lancet, 2, 411.

Kaplan, H. S., and Smithers, D. W. (1959). Ibid., 2, 1.

MacKay, I. R., and Burnet, F. M. (1962). Auto-immune Diseases. Thomas, Springfield, Illinois.

Marshall, A. H. E., and Wood, C. (1957). F. Path. Bact., 73, 163.

Miescher, P., and Vorlaender, K. O. (1957). Immunopathologie in Klinik und Forschung. Georg Thieme Verlag, Stuttgart.

Miller, D. G. (1962). Ann. intern. Med., 57, 703.

Ogryzlo, M. A. (1956). Canad. med. Ass. F., 75, 980.

Oliner, H., Schwartz, R., and Dameshek, W. (1961). Blood, 17, 20.

Razis, D. V., Diamond, H. D., and Craver, L. F. (1959). Amer. F. med. Sci., 238, 327.

Schier, W. W., Roth, A., Ostroff, G., and Schrift, M. H. (1956). Amer. f. Med., 20, 94 .

Simonsen, M. (1962). in Progress in Allergy, Vol. 6, p. 349, edited by P. Kallós and B. H. Waksman. Karger, Basle and New York.

Teitelbaum, J. I., Wiener, J., and Desforges, J. F. (1959). F. Lab. clin. Med., 53, 535.

Thomson, A. D. (1955). Brit. F. Cancer, 9, 37.

Waksman, B. H. (1962). Medicine (Baltimore), 41, 93.

Wall, R. L. (1958). Arch. intern. Med., 102, 618.

Williams, H. M., Diamond, H. D., Craver, L. F., and Parsons, H. (1959). Neurological Complications in Lymphomas and Leukaemias. Thomas, Springfield, Illinois.

\section{Medical Memoranda}

\section{Intestinal Explosion After Opening a Caecostomy with Diathermy}

\section{Brit. med. F., 1965, 1, 1594-1595}

While intestinal gases have been known to produce inflammable and even explosive mixtures (Lancet, 1947) an actual explosion is a rare event. Few cases are reported in the literature, and this is not altogether surprising considering how widespread is the practice of opening colostomies and caecostomies with the diathermy and cautery without any untoward result (Grey Turner and Rogers, 1955-6).

The following case report will therefore be of interest to those who routinely employ this method.
The patient, a 73-year-old hypertensive woman with a previous history of angina, was submitted to laparotomy for resection of a carcinoma of the rectosigmoid colon previously proved by biopsy taken through a sigmoidoscope.

The laparotomy was performed via a long left lower paramedian incision, and the presence of an encircling and obstructing carcinoma of the rectosigmoid was confirmed. A moderate degree of distension of the proximal colon was present owing to faeces and flatus, but the obstruction was not complete.

As large secondary deposits were present in the liver as well as local glandular spread, a palliative resection was performed to remove the primary growth and an end-to-end anastomosis performed over a rectal tube to reconstitute the colon. This procedure was entirely unremarkable and the patient's condition remained satisfactory throughout.

Before closure of the abdominal wound a caecostomy was prepared via a muscle-splitting incision in the right iliac fossa, and 